\title{
Hepatitis B Virus: Molecular Virology and Common Mutants
}

\author{
Tim J. Harrison, Ph.D., D.Sc., F.R.C.(Path.) ${ }^{1}$
}

The publisher regrets typographical errors in some of the labels in Fig. 1 of the above article in Seminars in Liver Disease, Volume 26, Number 2, 2006, p. 89. The corrected figure appears on the opposite page (p. 305).

\footnotetext{
${ }^{1}$ Reader in Molecular Virology, UCL Institute of Hepatology, University College London, London, United Kingdom.

Address for correspondence and reprint requests: Tim J. Harrison, Ph.D., D.Sc., F.R.C.Path., Reader in Molecular Virology, UCL Institute of Hepatology, University College London, Windeyer Building, 46
}

The Control of Chronic Hepatitis B: The Role for Chemoprevention; Guest Editor, Stephen A. Locarnini, M.B.B.S., Ph.D., F.R.C.(Path.). Semin Liver Dis 2006;26:304-306. Copyright (C) 2006 by Thieme Medical Publishers, Inc., 333 Seventh Avenue, New York, NY 10001, USA. Tel: +1(212) 584-4662.

DOI 10.1055/s-2006-947300. ISSN 0272-8087. 


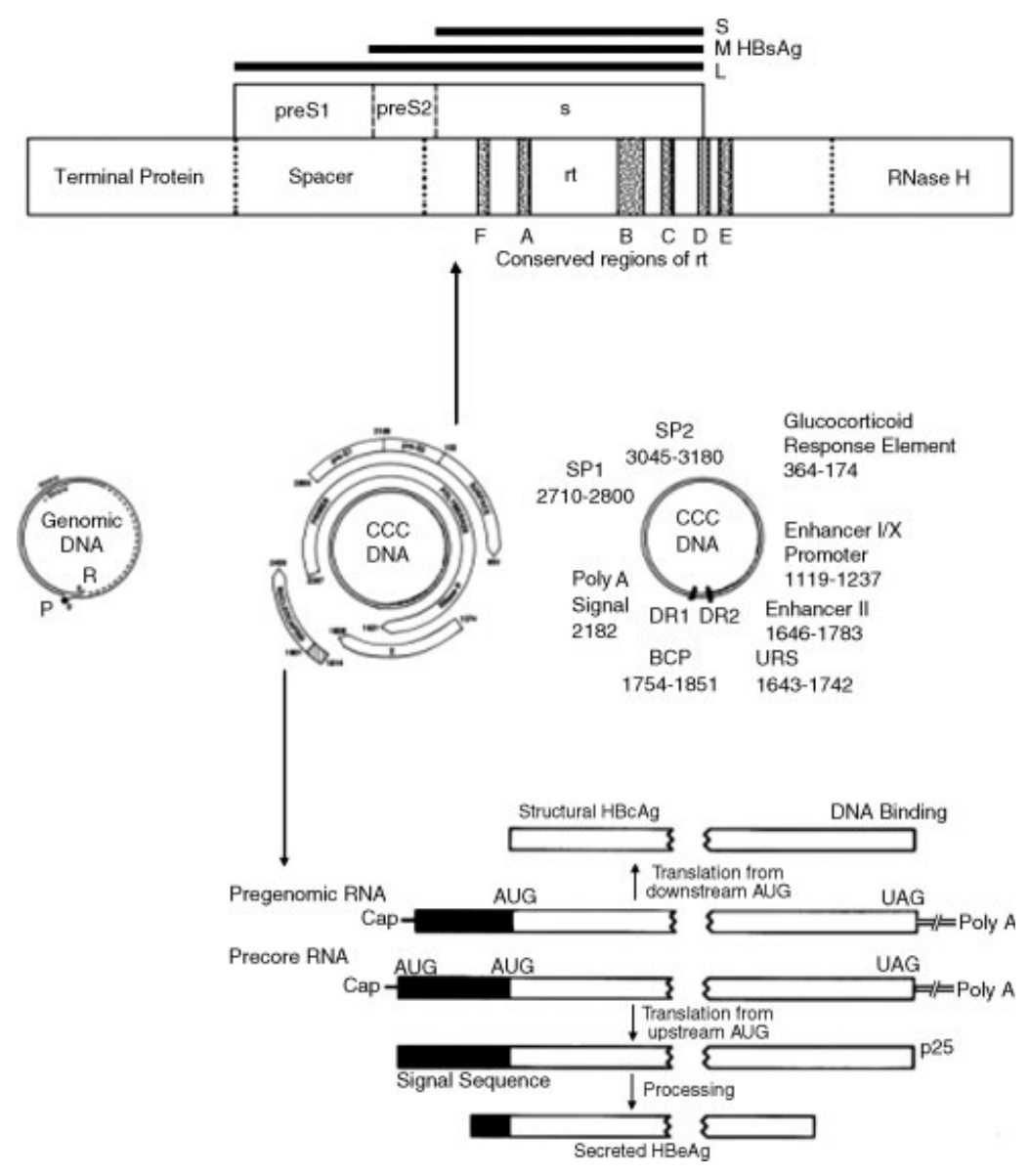

Figure 1 Hepatitis B virus (HBV) gene expression. The center section shows the viral DNA; on the left, the characteristic partially single-stranded circular form of the genome that resembles a replicative intermediate $(P$, minus strand protein primer; $R$, plus strand oligoribonucleotide primer). The four overlapping open reading frames (ORFs) are shown in the middle of the section; all nucleotides encode protein and around half are in regions where the ORFs overlap. The four promoters and all other cis-acting sequences (shown to the right) are embedded within the ORFs. The upper section gives more details of the overlapping polymerase and surface genes, including the domains of the polymerase and the conserved regions within the rt domain. The lower section shows the synthesis of $\mathrm{HBcAg}$ and $\mathrm{HBeAg}$ from the pregenomic and precore RNAs. 
